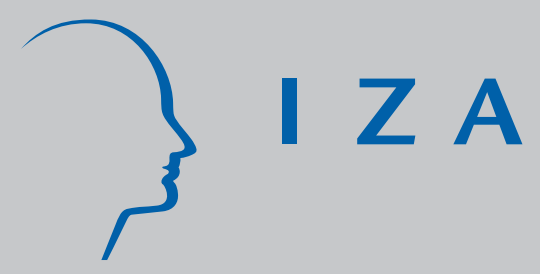

IZA DP No. 3557

Short-Run Distributional Effects of Public Education Transfers to Tertiary Education Students in Seven European Countries

Tim Callan

Tim Smeeding

Panos Tsakloglou

J une 2008 


\title{
Short-Run Distributional Effects of Public Education Transfers to Tertiary Education Students in Seven European Countries
}

\author{
Tim Callan \\ Economic and Social Research Institute \\ and IZA \\ Tim Smeeding \\ Syracuse University \\ Panos Tsakloglou \\ Athens University of Economics and Business \\ and IZA \\ Discussion Paper No. 3557
June 2008 \\ IZA \\ P.O. Box 7240 \\ 53072 Bonn \\ Germany \\ Phone: +49-228-3894-0 \\ Fax: +49-228-3894-180 \\ E-mail: iza@iza.org
}

Any opinions expressed here are those of the author(s) and not those of IZA. Research published in this series may include views on policy, but the institute itself takes no institutional policy positions.

The Institute for the Study of Labor (IZA) in Bonn is a local and virtual international research center and a place of communication between science, politics and business. IZA is an independent nonprofit organization supported by Deutsche Post World Net. The center is associated with the University of Bonn and offers a stimulating research environment through its international network, workshops and conferences, data service, project support, research visits and doctoral program. IZA engages in (i) original and internationally competitive research in all fields of labor economics, (ii) development of policy concepts, and (iii) dissemination of research results and concepts to the interested public.

IZA Discussion Papers often represent preliminary work and are circulated to encourage discussion. Citation of such a paper should account for its provisional character. A revised version may be available directly from the author. 


\begin{abstract}
Short-Run Distributional Effects of Public Education Transfers to Tertiary Education Students in Seven European Countries*

Direct provision of public services can alter the balance of resources across income groups. We focus on the issues arising when taking account of the impact of publicly provided education services across the income distribution. We combine OECD information on spending per student in particular levels of the education system with micro data from nationwide income surveys to track the allocation of resources. We pay particular attention to the role of third level education, and provide comparable results for seven European countries (Belgium, Germany, Greece, Italy, Ireland, the Netherlands and the UK).
\end{abstract}

JEL Classification: $\quad$ I28, D31, H42

Keywords: inequality, in-kind transfers, tertiary education, Europe

Corresponding author:

Panos Tsakloglou

Department of International and European Economic Studies

Athens University of Economics and Business

76 Patission Street

Athens 10434

Greece

E-mail: panos@aueb.gr

\footnotetext{
* Research carried out in the framework of the EU-supported research project "Accurate Income Measurement for the Assessment of Public Policies (AIM-AP)". The authors would like to thank the project coordinator Holy Sutherland, as well as Joachim Frick, Markus Grabka, Tim Goedemé, Olaf Groh-Samberg, Christos Koutsambelas, Mattia Makovec, Gerlinde Verbist, Klaas de Vos and Francesca Zantomio for providing a number of estimates reported in the paper as well as offering comments and suggestions.
} 


\section{Introduction}

Cross-national analyses of welfare state transfers and their effects on inequality usually produce large differences amongst OECD nations. Most of the differences in inequality are due to cross national differences in the distribution of earnings and especially in 'cash and near cash welfare state transfers' (Atkinson et al 1995; Gustafsson and Johansson 1999; Kenworthy 2004). Scandinavian and Nordic countries are big spenders in cash terms and reduce inequality the most. English speaking countries spend the least and reduce inequality the least, while the continental European countries spend a lot, but achieve less equality than the Scandinavians. Southern European nations spend the least and have the highest inequality (Heady et al 2001; Dennis and Guio 2003; Förster and Mira d'Ercole 2004; Garfinkel et al 2006).

These cross national differences support welfare state theories such as those of Titmus (1958) and Esping-Andersen (1990) concerning distinct welfare state regimes. A major limitation of the research on the effects of the welfare state on poverty and other distributional outcomes is that the analyses of transfers and their effects on inequality are restricted to cash or near cash transfers only. Yet in all of these rich countries, about half of welfare state transfers consist of in-kind benefits such as education, health insurance, child care, elderly care and other services. In-kind as well as cash transfers reduce inequalities in standards of living as documented in research within selected countries but only occasionally cross nationally.

Most importantly, 'welfare state' theorists rarely include education in their analyses of the welfare state. This tendency is strengthened by the institutional stances of the OECD and other bodies which publish annual series of 'Social Welfare Expenditures' that explicitly exclude education, leaving it to another entirely different annual series ("Education at a Glance”). It is as if health and cash benefits are the only ways in which the state supports the needs of families for basic income support and building of human capabilities. But of course, in the $21^{\text {st }}$ century, education is likely to be the most sought after and most productive method of building human capital and strengthening the economic position of nations and their citizens. This leads to a high demand and high value for good quality schools, especially for institutions of higher learning. 
The theoretical and empirical importance of valuing in-kind benefits has been understood for nearly a quarter century (Smeeding 1977). Conceptually it is clear that these benefits are worth some nontrivial amount to beneficiaries. Thus, from a theoretical point of view, a measure that counts in-kind transfers is superior to the conventional measure of cash disposable income as a measure of a household's standard of living (Atkinson and Bourguignon 2000; Atkinson et al 2002; Canberra Group 2001). The first cross national study of inequality to incorporate health and education (Smeeding et al 1993) found only small changes in cross national differences, with the exception of Great Britain. However, these researchers used data from the 1980s when health care and education played a much smaller role than they now do, and included only 7 nations in total, with just three from the EU (Germany, Netherlands, UK) and no southern European countries. Moreover, their education benefits were limited to elementary and secondary schooling only, with no value for tertiary education.

A number of more recent studies using cross-national information and employing a variety of techniques to examine the distributional effects of in-kind public transfers suggest that public education transfers reduce aggregate inequality (Whiteford and Kennedy 1995; Steckmest 1996; Harding et al 2006; Garfinkel et al 2006; Marical et al 2006). Similar evidence is reported in a number of national studies (Lampman 1984; James and Benjamin 1987; Evandrou et al 1993; McLennan 1996; Huguenenq 1998; Tsakloglou and Antoninis 1999; Harris 2000; Antoninis and Tsakloglou 2001; Sefton 2002; Lakin 2004). In quantitative terms, cross-country differences seem to be substantial, but it is not always clear whether such differences are genuine or can be attributed to methodological choices made by the researchers (detail of information available, treatment of tertiary education students and their families, etc.).

The purpose of this paper is to extend previous analyses of the distributional effects of welfare state programs in rich countries by taking into account the effect of education transfers on economic inequality in seven EU countries (Belgium, Germany, Greece, Italy, Ireland, the Netherlands and the UK), in a strictly comparable framework. We argue that there are good reasons to pay special attention to the 
impact of spending for non-compulsory and, above all, tertiary education on relative economic welfare. Thus, in the present paper, we focus in particular on higher education while similar analyses for a broader definition of education spending can be found in Callan et al (2007).

As far as we know, our study is among the first to focus on tertiary education and its distributional consequences. Indeed, as the world demand for labour turns increasingly to high skill workers, expenditures on tertiary education systems and tertiary education reform will be high in the EU agenda for decades to come (Jacobs and van der Ploeg 2006).

\section{Education Systems}

The distribution of benefits from public expenditure on education depends heavily on the scale and structure of the educational system. The systems in the seven European countries considered here have much in common. Broadly speaking, schooling is free ${ }^{1}$ and compulsory for primary and lower secondary education, and also free of tuition fees (but not always compulsory) for upper secondary education.

At third level, there is more variation in fees, but there remains a very substantial public subsidy in all countries. This support almost always includes subsidies to the cost of tuition (so that fees do not have to cover the full cost of services provided); and direct aid, via grants or loans, for students' living expenses and stipends. The extent of such support may vary depending on whether or not the student is living with his or her parents, the degree of perceived financial need or the level of scholarship of the student (Jacobs and van der Ploeg 2006). In the surveys employed in this paper, direct subsidies in the form of student living cost stipends are measured as cash incomes in the household where they reside. This is not the case for other types of subsides. Here we focus on other and uncounted non-cash subsidies arising from the fact that fees do not cover the cost of providing third level education. ${ }^{2}$

1. That is, school is free in the sense that there are no tuition fees; ancillary costs of participation (such as books or school uniforms, etc) may fall on parents in some countries and may be subsidized in part by governments or schools.

2. The treatment of loans merits further attention, but the subsidy arising from loans is limited to the gap between the interest rate charged and the opportunity cost of funds. See Dearden et al (2008) on 
A number of the cross-country differences that are likely to influence the results reported below have to do with the incidence of private education and the possibility of within-country differentiation of the size of the transfers to students of particular levels of education (for example, due to the existence of federal funding systems and gradated levels of universal vs. college-specific spending). The most significant cross-country differences are likely to emanate from differences in spending for non-compulsory levels of education. Where participation in education is compulsory, or close to universal even if not compulsory, the distribution of the benefits from public expenditure will tend to flow equally to the relevant age cohort. ${ }^{3}$ But where participation is neither compulsory nor complete, as in third level education (and in some countries, in upper secondary level), then socio-economic differences in the pattern of participation can have a significant influence on the distributive impact of state expenditure.

Table 1. School-leaving age and participation in education, 2004

\begin{tabular}{cccc}
\hline Country & $\begin{array}{c}\text { Ending age of compulsory } \\
\text { education }\end{array}$ & $\begin{array}{c}\text { No. of years for which } \\
\text { over 90\% of population } \\
\text { are enrolled }\end{array}$ & $\begin{array}{c}\text { Age range at which over } \\
\text { 90\% of population are } \\
\text { enrolled }\end{array}$ \\
\hline Belgium & 18 & 16 & 3 to 18 \\
Germany & 18 & 12 & 6 to 17 \\
Greece & 14.5 & 12 & 6 to 19 \\
Ireland & 15 & 12 & 5 to 16 \\
Italy & 15 & 13 & 3 to 15 \\
Netherlands & 18 & 12 & 5 to 16 \\
UK & 16 & 13 & 4 to 16 \\
\hline
\end{tabular}

Source: OECD (2006), Table C1.2

In order to clarify this point, Table 1 shows how countries vary in the age at which compulsory schooling ends, and the age range over which participation in education is more than 90 per cent of the cohort. Three countries have a "school income contingent loans employed for paying tuition in Australia and, recently, in the United Kingdom, and other nations, but not in the nations studied here at the time period covered by our study. 3. Where different forms of schooling are on offer to an age group, with differing costs of provision, differences can emerge depending on the pattern of participation across school types. 
leaving age” (the age at which compulsory education ends) of 18, whereas the others have a school leaving age close to 15 . However, looking at actual participation in education we find that with one exception, the age range over which more than $90 \%$ of the cohort is enrolled in school spans a period of either 12 or 13 years. In other words, there is greater uniformity in terms of actual years of school attendance than in terms of the statutorily compulsory ages. ${ }^{4}$

Table 2. Entry rates into tertiary education, 2004

\begin{tabular}{ccc}
\hline Country & $\begin{array}{c}\text { Tertiary type A } \\
\text { (mainly University) } \%\end{array}$ & $\begin{array}{c}\text { Tertiary type B } \\
\text { (mainly technical/vocational) \% }\end{array}$ \\
\hline Belgium & 34 & 35 \\
Germany & 37 & 16 \\
Greece & 33 & 26 \\
Ireland & 44 & 17 \\
Italy & 55 & 1 \\
Netherlands & 56 &.$\cdot$ \\
UK & 52 & 28 \\
\hline
\end{tabular}

Source: OECD (2006), Table C1.2

There is much greater variation across the countries in the level and composition of third-level enrolment, as seen in Table 2. Third level entry rates vary from about 50 per cent (Germany and Greece) to rates of 70 to 80 per cent (Belgium and the UK). Furthermore, the composition of the third level sector, as between university-type education and more specialised technical or vocational qualifications is quite different. Differences in third level participation may arise from several sources, including differences in the structure of the earlier levels of education e.g., whether specialisation in more academic type of education tends to take place at an earlier or later stage, and differences in labour demand within each country.

4. The exception is Belgium, where the pre-school phase has also been included in the OECD figures. Here, however, we focus on the benefits deriving from public expenditure on primary, secondary and tertiary education only. 


\section{Data and methods}

The estimates derived in the next section rely on static incidence analysis under the assumption that public education transfers do not create externalities. No dynamic effects are considered in the present analysis. In other words, it is assumed that the beneficiaries of the public transfers are exclusively the recipients of the public education services (and the members of their households) and that these services do not create any benefits or losses to the non-recipients. ${ }^{5}$ Moreover, it is assumed that the value of the transfer to the beneficiary is equal to the average cost of producing the public education services in the corresponding level of education. Similar assumptions are standard practice in the analysis of the distributional impact of publicly provided services (Smeeding et al 1993; Jones 2006; Marical et al 2006; Garfinkel et al 2006).

For the purposes of our analysis, information on spending per student in primary, secondary and tertiary education derived from OECD (2006) is combined with micro-level information from nationwide income surveys. Each student in a public education institution (or a heavily subsidized private education institution) in the nationwide income survey is assigned a public education transfer equal to the average cost of producing these services in the corresponding level of education. Then, this benefit is assumed to be shared by all household members. In other words, it is implicitly assumed that in the absence of public transfers the students and their families would have to undertake the expenditures themselves. The national databases used in the analysis and the corresponding reference years are shown in Table 3. In a companion paper (Callan et al, 2007) we present detailed results on effects of public transfers to each level of education (primary, secondary and tertiary). Here, we focus primarily on the effects of tertiary education transfers.

5. It may be argued that external benefits are rather small and are mainly limited to the primary years of schooling where basic literacy and civil behavior are taught. See Wilson, et al, (2006) for a discussion of spillover benefits who calculate that about 10 percent of public spending for elementary and tertiary schooling creates external benefits to society at large in the United States. These spillovers should be pure public goods and therefore may be considered distributionally neutral. 
Table 3. National income data sets used in the analysis

\begin{tabular}{ccc}
\hline Country & Dataset & $\begin{array}{c}\text { Reference } \\
\text { year }\end{array}$ \\
\hline Belgium (BE) & European Union - Statistics on Income and Living & 2003 \\
Conditions (EU-SILC) & \\
Germany (D) & German Socio-Economic Panel Study (SOEP) & 2001 \\
Greece (GR) & Household Budget Survey & 2004 \\
Ireland (IR) & Living in Ireland Survey & 2000 \\
Italy (IT) & European Union - Statistics on Income and Living & 2003 \\
& Conditions (EU-SILC) & 2001 \\
Netherlands (N) & Socio-Economic Panel Survey & 2003 \\
United Kingdom (UK) & Family Resources Survey & \\
\hline
\end{tabular}

Estimates of public spending per student in primary, secondary and tertiary public education institutions were derived as follows. Figures from Table X2.5 (p. 434) of OECD's “Education at a glance 2006” (Annual expenditure on educational institutions per student for all services (2003) in equivalent euros converted using $P P P$, by level of education based on full-time equivalents) were multiplied by the estimates of the share of public expenditures in total educational expenditures (separately for tertiary and non-tertiary education) reported in Table B2.1b (p. 206) (Expenditure on educational institutions as a percentage of GDP by level of education (1995, 2000, 2003) from public and private sources by source of funds and year) and euro PPP conversion rates as reported in Table X2.2 (p. 431) (Basic reference statistics (reference period: calendar year 2003, 2003 current prices). In order to derive the corresponding estimates for years other than 2003, these estimates were inflated or deflated using country specific nominal GDP per capita conversion factors derived from the data of the on-line OECD database (using real GDP growth rates, GDP deflators and population growth rates). The estimates in current euros are shown in Table $4{ }^{6}$

6. US studies indicate that public school spending per pupil may differ by up to 50 per cent between rich and poor districts. (e.g., Wilson, Lambright and Smeeding, 2006). In the absence of similar studies, we are unable to consider this factor here; but this is an area warranting further research. 
Table 4. Public spending per student in three educational levels (in current euros)

\begin{tabular}{ccccc}
\hline \multirow{2}{*}{ Country } & \multicolumn{4}{c}{ Level of education } \\
\cline { 2 - 4 } & Primary & Secondary & $\begin{array}{c}\text { Tertiary } \\
\text { (with R\&D) }\end{array}$ & $\begin{array}{c}\text { Tertiary } \\
\text { (without R\&D) }\end{array}$ \\
\hline Belgium 2003 & 4662 & 5814 & 8440 & 5809 \\
Germany 2001 & 3131 & 4857 & 8613 & 5410 \\
Greece 2004 & 2541 & 2984 & 3634 & 2772 \\
Ireland 2000 & 3291 & 4407 & 6060 & 4687 \\
Italy 2003 & 5310 & 5723 & 5055 & 3264 \\
Netherlands 2001 & 4250 & 5095 & 8174 & 5069 \\
UK 2003 & 2804 & 3495 & 4757 & 3660 \\
\hline
\end{tabular}

Source: Own calculation based on OECD (2006), Tables X2.5, B2.1b and X2.2

In all countries public spending per secondary education student is higher than for primary education students. In some countries such as Germany, Ireland and Belgium the differences are quite large, while in others, such as Italy and Greece, the differences appear to be relatively small. Comparisons of spending per student in secondary and tertiary education depend on the treatment of public R\&D expenditures. It is very likely that activities financed by such expenditures have positive spillover effects to students; however, their main beneficiaries are not the students per se. For this reason, in the following analysis we present estimates derived from public transfers to tertiary education students net of R\&D public expenditures. ${ }^{7}$

In the case of tertiary education students living away from their parental homes there is the broader question of whether the equivalised household income per capita is a good approximation of their standard of living. Typically, in most empirical studies, such students who do not live in collective households are treated as independent units. This approach risks attributing an unwarranted benefit to low income groups, simply because students living away from high income homes, have temporarily low incomes during their student years; while the literature on the returns

7. Estimates reported in Callan et al (2007) suggest that the findings of the paper do not change substantially when public transfers to tertiary education students include R\&D spending. It should be noted that the figures in Table 4 are influenced by the particular way used by the OECD in order to calculate the average number of years of tertiary education studies and, consequently, the number of full-time equivalent students in each country. 
to education indicates that their likely positions in the earnings distribution will later be towards the top of the distribution . Moreover, the living arrangements of tertiary education students differ substantially across countries and finally, their treatment in the national surveys in not always the same. For example, most of tertiary education students in Greece live with their parents whereas this is the case of relatively few such students in the Netherlands, while in Belgium and Italy, students living in collective households (such as student accommodation) are treated as members of their parental households. Further, as 'students' move into their late 20's, they may well become financially independent of their parents, in which case the student alone or with partner may be a more the appropriate unit. While tertiary school enrolments have increased substantially over the past two decades, tertiary education students are taking an increasingly long period to complete their studies. Thus the issue of the economic independence of tertiary students will continue to grow in importance in coming decades (Bell et al, 2007). As a result, the distributional effects of public transfers to tertiary education students are not always strictly comparable across countries. Hence, the next section reports results both for all tertiary education students and for tertiary education students living with their parents only.

Radner (1997) points out that in standard analysis of the distribution of cash income, equivalence scales are used to adjust for the differing needs of households of different size and composition. When health or education services are included in the measure of resources, he argues that differing needs for health and education services should also be taken into account. Just as the welfare of an elderly person can be overstated by including the insurance value of publicly provided health cover (Smeeding, 1982b) the welfare of a family with children can be overstated by including the value of non-cash education benefits, without taking account of the educational needs of the children. With this point in mind, we focus on third level education. In the case of compulsory education arguments concerning the existence of educational needs, precisely corresponding to publicly-provided services, are strongest. The analysis of the distribution of benefit from non-compulsory education can be regarded as an alternative focus, less susceptible to the Radner critique and more a result of the choices made by parents and students. 
Finally, when dealing with taxes and cash transfers it is standard practice to regard as progressive a policy or set of policies which yield higher proportionate gains for lower income groups. In the present framework, non-cash benefits are "cashed out” and aggregated with cash income, and the same criteria for progressivity apply higher proportionate gains for the lower income groups, raising their share of total income or resources. By this criterion, an education policy can be progressive even if it gives much greater absolute value to higher income groups (but less than in line with their income share). An alternative and perhaps more appropriate benchmark for a neutral education policy would be that it gave the same absolute value to all. Nevertheless, this is not the standard approach adopted in distributional studies and, hence, it is not applied here.

\section{Empirical results}

We start by reporting the position of the beneficiaries of tertiary public education subsidies in the income distribution when the population is grouped in quintiles according to their disposable income. The distributions used are distributions of equivalised household disposable income per capita and they are derived using the "modified OECD equivalence scales" that assign weights of 1 to the household head, 0.5 to each of the remaining adults in the household and 0.3 to each child (person aged below 14) in the household. Table 5a shows the location of all such beneficiaries, while Table $5 \mathrm{~b}$ focuses exclusively on those who live with their parents. For the reasons described in the previous section, it is the latter group that provides a better picture of the short-run distributional effects of public transfers in tertiary education. For two countries - Belgium and Italy - the two sets of estimates are identical since in these countries tertiary education students living away from their parents were classified as members of the parental household. The share of tertiary education students living with their parents differs substantially across countries and this is likely to have a strong influence on cross-country comparisons. In some countries, the beneficiaries of public tertiary education are more likely to be found around the middle of the income distribution whereas in the Netherlands they are strongly overrepresented in the bottom quintile and in the UK there is a clear positive association between the share of the beneficiaries and the quintile of the income distribution to which they belong. However, in Table 5b, where the focus is 
exclusively on the sub-group of tertiary education students who live with their parents, the picture that emerges in all countries apart from the Netherlands is broadly similar: the higher the quintile, the higher the share of beneficiaries. In Netherlands, most of the (relatively small group) of beneficiaries who live with their parents are located in the second and the third quintile.

Table 5a. Distribution of beneficiaries of third-level education by household income quintile

\begin{tabular}{cccccc}
\hline & \multicolumn{5}{c}{ Quintile } \\
\cline { 2 - 6 } & Bottom & $2^{\text {nd }}$ & $3^{\text {rd }}$ & $4^{\text {th }}$ & Top \\
\hline B & 17.6 & 16.8 & 20.4 & 24.7 & 20.4 \\
D & 22.5 & 13.3 & 19.6 & 19.6 & 25.4 \\
GR & 17.6 & 24.8 & 20.7 & 19.6 & 17.3 \\
IR & 17.6 & 24.8 & 20.7 & 19.6 & 17.3 \\
IT & 19.4 & 18.1 & 18.5 & 19.9 & 24.1 \\
NL & 39.0 & 19.1 & 16.0 & 12.8 & 13.2 \\
UK & 16.0 & 15.5 & 20.9 & 23.8 & 24.0 \\
\hline
\end{tabular}

Table 5b. Distribution of beneficiaries of third-level education by household income quintile, excluding students living away from parental home

\begin{tabular}{cccccc}
\hline & \multicolumn{5}{c}{ Quintile } \\
\cline { 2 - 6 } & Bottom & $2^{\text {nd }}$ & $3^{\text {rd }}$ & $4^{\text {th }}$ & Top \\
\hline B & 17.6 & 16.8 & 20.4 & 24.7 & 20.4 \\
D & 6.5 & 9.7 & 25.8 & 27.7 & 30.3 \\
GR & 9.2 & 17.0 & 22.3 & 25.7 & 25.8 \\
IR & 9.2 & 17.0 & 22.3 & 25.7 & 25.8 \\
IT & 19.4 & 18.1 & 18.5 & 19.9 & 24.1 \\
NL & 15.1 & 29.0 & 25.9 & 17.3 & 12.7 \\
UK & 15.1 & 13.7 & 21.5 & 28.7 & 21.1 \\
\hline
\end{tabular}

Tables $6 \mathrm{a}$ and $6 \mathrm{~b}$ report the relative ratio of actual beneficiaries to potential beneficiaries of third level education. For the construction of this indicator, first the number of the quintile's members who benefit from public tertiary education transfers is divided by the total number of persons in the corresponding age bracket. The age brackets are country specific and correspond to the typical age brackets that 
population members attend tertiary education. In the next stage, the resulting ratio of each quintile and educational level is divided by the corresponding national ratio. As a result, figures above (below) one imply that the members of the corresponding quintile are overrepresented (underrepresented) among the beneficiaries of public tertiary education transfers. In Table 6a, which includes students living away from the parental home, differences across quintiles are not dramatic, although in most cases the ratio is below one in the lower quintiles and higher than one in the top quintiles. However, when we focus exclusively on tertiary education beneficiaries living with their parents (Table 6b), the evidence in most countries shows that the ratio of actual to potential beneficiaries is substantially higher at the top than close to the bottom of

Table 6a. Relative ratio of actual to potential beneficiaries, third level

\begin{tabular}{cccccc}
\hline & \multicolumn{5}{c}{ Quintile } \\
\cline { 2 - 6 } & Bottom & $2^{\text {nd }}$ & $3^{\text {rd }}$ & $4^{\text {th }}$ & Top \\
\hline B & 0.76 & 0.91 & 1.15 & 1.12 & 1.00 \\
D & 0.97 & 0.61 & 0.92 & 1.05 & 1.63 \\
GR & 0.89 & 1.08 & 0.89 & 1.06 & 1.17 \\
IR & 0.86 & 1.14 & 0.81 & 1.17 & 0.95 \\
IT & 0.85 & 1.00 & 0.98 & 1.00 & 1.19 \\
NL & 1.74 & 1.10 & 0.94 & 0.71 & 0.47 \\
UK & 0.94 & 1.09 & 1.19 & 0.97 & 0.88 \\
\hline
\end{tabular}

Table 6b. Relative ratio of actual to potential beneficiaries, third level, excluding students living away from parental home

\begin{tabular}{cccccc}
\hline & \multicolumn{5}{c}{ Quintile } \\
\cline { 2 - 6 } & Bottom & $2^{\text {nd }}$ & $3^{\text {rd }}$ & $4^{\text {th }}$ & Top \\
\hline B & 0.76 & 0.91 & 1.15 & 1.12 & 1.00 \\
D & 0.30 & 0.45 & 1.17 & 1.41 & 1.87 \\
GR & 0.52 & 0.81 & 0.93 & 1.26 & 1.52 \\
IR & 0.89 & 1.16 & 0.78 & 1.11 & 0.97 \\
IT & 0.85 & 1.00 & 0.98 & 1.00 & 1.19 \\
NL & 1.24 & 1.22 & 1.10 & 0.87 & 0.62 \\
UK & 0.78 & 0.83 & 1.06 & 1.17 & 1.11 \\
\hline
\end{tabular}


the income distribution. This pattern is particularly pronounced in Germany and Greece and, to a slightly lesser extent, the UK. The only country where the evidence points to the opposite direction is the Netherlands.

Table 7. Increase in disposable income due to tertiary education transfers by quintile

\begin{tabular}{cccccc}
\hline & \multicolumn{5}{c}{ Quintile } \\
\cline { 2 - 6 } & Bottom & $2^{\text {nd }}$ & $3^{\text {rd }}$ & $4^{\text {th }}$ & Top \\
\hline B & 4.2 & 2.7 & 2.6 & 2.4 & 1.2 \\
D & 3.1 & 0.9 & 0.8 & 0.7 & 0.5 \\
GR & 2.1 & 1.6 & 1.1 & 0.8 & 0.4 \\
IR & 2.0 & 3.5 & 1.8 & 1.8 & 0.7 \\
IT & 3.7 & 2.0 & 1.5 & 1.2 & 0.8 \\
NL & 5.5 & 1.5 & 1.1 & 0.6 & 0.4 \\
UK & 3.0 & 1.8 & 1.7 & 1.4 & 0.8 \\
\hline
\end{tabular}

Next we turn to the value of the public transfers for third level education as a share of the aggregate quintile disposable income (Table 7). Since the denominator in these calculations is the income share of the corresponding quintile, ceteris paribus, transfers of equal size will translate into larger proportional increases in the cases of quintiles with smaller shares in aggregate disposable income and with the same number of beneficiaries (students) per quintile. The size of the distributional impact of the education system depends, therefore, not just on the size and structure of the education system, but also on the pre-existing distribution of disposable income. In other words, similar education systems in two countries would have a greater impact in the more unequal country. Hence, cross-country comparisons should be interpreted with this factor in mind. The relatively low impact of tertiary education transfers in comparison to the two other levels of the education system (see Callan et al, 2007) should be attributed to the fact that, despite the high value of the annual transfer per tertiary education student, unlike the other two educational levels, participation in this educational level is very far from universal. .Further, tertiary education studies are usually shorter than those in either primary or secondary education, thus concentrating benefits over a shorter time horizon. In almost all countries, the share of transfers in quintile disposable income declines monotonically as we move up the income 
distribution. In some cases these declines are fairly steep (such as in the Netherlands where these transfers are equal to $5.5 \%$ and $0.4 \%$ of the disposable income of the bottom and top quintiles), while in others far less so (such as in Greece, where the corresponding figures are $2.1 \%$ and $0.4 \%$ ).

Table 8a. Proportional reduction in inequality due to tertiary education transfers and all education transfers taken together

\begin{tabular}{ccccccc}
\hline & \multicolumn{6}{c}{ Change in inequality due to } \\
\cline { 2 - 7 } & \multicolumn{2}{c}{ Tertiary education transfers } & \multicolumn{3}{c}{ All education transfers } \\
\cline { 2 - 7 } & Gini & Atkinson 0.5 & Atkinson 1.5 & Gini & Atkinson 0.5 & Atkinson 1.5 \\
\hline B & -0.6 & -1.4 & -0.7 & -7.1 & -14.1 & -13.0 \\
D & -0.6 & -1.3 & -1.3 & -6.7 & -12.3 & -12.4 \\
GR & -0.5 & -0.9 & -0.7 & -6.6 & -12.3 & -11.4 \\
IR & -0.7 & -1.1 & -0.4 & -9.6 & -16.8 & -11.6 \\
IT & -0.9 & -1.9 & -2.0 & -8.9 & -16.7 & -18.0 \\
NL & -1.3 & -3.1 & -4.1 & -11.1 & -20.5 & -20.4 \\
UK & -0.8 & -1.7 & -2.7 & -8.0 & -14.0 & -12.9 \\
\hline
\end{tabular}

Table 8b. Proportional reduction in inequality due to tertiary education transfers and all education transfers taken together, excluding students living away from parental home

\begin{tabular}{|c|c|c|c|c|c|c|}
\hline & \multicolumn{6}{|c|}{ Change in inequality due to } \\
\hline & \multicolumn{3}{|c|}{ Tertiary education transfers } & \multicolumn{3}{|c|}{ All education transfers } \\
\hline & Gini & Atkinson 0.5 & Atkinson 1.5 & Gini & Atkinson 0.5 & Atkinson 1.5 \\
\hline B & -0.6 & -1.4 & -0.7 & -7.1 & -14.1 & -13.0 \\
\hline $\mathrm{D}$ & 0.1 & 0.1 & 0.3 & -6.1 & -11.2 & -11.1 \\
\hline GR & -0.1 & -0.2 & -0.1 & -6.3 & -11.8 & -10.9 \\
\hline IR & -0.7 & -1.2 & -0.5 & -9.6 & -16.9 & -11.6 \\
\hline IT & -0.9 & -1.9 & -2.0 & -8.9 & -16.7 & -18.0 \\
\hline NL & -0.3 & -0.7 & -1.3 & -10.2 & -18.7 & -18.2 \\
\hline UK & -0.3 & -0.5 & -0.3 & -7.5 & -13.0 & -10.3 \\
\hline
\end{tabular}

Tables $8 \mathrm{a}$ and $8 \mathrm{~b}$ reports the proportional change in a number of inequality indices when we move from the distribution of disposable income to the distribution of disposable income augmented by the public transfers via third level education only (left panel) and via transfers to all educational levels (right panel). As inequality 
indices we chose the widely used Gini index and two members of the parametric family of Atkinson (1970) indices. The value of the inequality aversion parameter in the latter is set at $(\mathrm{e}=0.5$ and $\mathrm{e}=1.5) .{ }^{8}$ The results reported in the right panels of Tables $8 \mathrm{a}$ and $8 \mathrm{~b}$ suggest that public education transfers reduce aggregate inequality quite substantially. In all cases, the recorded effects are larger when the Atkinson index is used, irrespective of the value of the inequality aversion parameter of the index. According to Table 8a, after the inclusion of public education transfers in the concept of resources, recorded levels of inequality decline between 6.6\% (Gini) and 11.4\% (Atkinson) in Greece and 11.1\% (Gini) and 20.5\% (Atkinson), in the Netherlands. The corresponding declines are slightly smaller in Table 8a, when students living away from parental home are excluded from the analysis. Comparing the results reported in the left and right panels of these tables it becomes evident that these declines in inequality are driven primarily from the effects of public education transfers at the primary and secondary levels. In Table 8a the declines in inequality due to tertiary education transfers are quite small and they become even smaller in Table $8 \mathrm{~b}$ when students living away from their parents are excluded from the sample (in Germany the direction of the change reverses and the transfers appear to produce marginal increases in inequality).

\section{Summary and Conclusions}

In this paper we have investigated the redistributive effects of in-kind public education transfers, focusing in particular on the role of tertiary education transfers. Most of the existing comparative studies of inequality and its determinants have either ignored in-kind transfers or have only dealt with limited amounts of public education transfers. Theoretically, full income, which counts in-kind transfers, is a superior measure of a household's command over resources than is the conventional measure of cash disposable income. The inclusion of education transfers is of particular interest, given the ongoing debate regarding the appropriate financing of higher level education and national investments in human capital.

\footnotetext{
8. Both indices satisfy the desirable properties for an inequality index (anonymity, mean independence, population independence, transfer sensitivity). Higher values of e make the Atkinson index relatively more sensitive to changes closer to the bottom of the distribution while, in practice, the Gini index is relatively more sensitive to changes around the median of the distribution (Lambert, 2001).
} 
We estimated only the private market benefits from education at government cost. The spillover benefits of education to the general populace, which may be as large as or larger than the direct effects, are not counted (Wolfe and Haveman 2003). Positive externalities arising from research and development benefits from education enterprise are also not counted. In both cases, external and “R\&D” benefits accrue to the entire populations and therefore might be considered distributionally neutral. The private benefits of education accrue mainly to the individuals and their families in terms of better jobs and higher earnings and spending power, and here we look only at the value of inputs, capital and operating expenses per pupil, not at their future value to the individual who receives them, though some new tertiary school funding mechanisms have created income contingent loans to claw back some of the tertiary schooling subsidies in a few countries, most notably in this context the United Kingdom (Dearden et al 2008).

We find that valuing in-kind education benefits at government cost increases disproportionally the real income of low income households and narrows substantially inequality. The effects of tertiary education are large per pupil, but accrue only to a minority of children as of this writing. Further, they are most difficult to value and distribute because students counted as independent units have low incomes, while the parental households from which tertiary students come are likely to be relatively rich. The results of sensitivity analysis suggest that attributing the corresponding public transfers to students living with their parents only rather than all students, alters the results concerning the distribution of third-level expenditures significantly as these benefits in a static framework appear to be mildly progressive, but in a dynamic framework may well reinforce inequalities from one generation to the next (Haveman and Smeeding 2006). The introduction of income contingent student loans as a source of payment for tuition and fees for tertiary schooling may be seen as a way to reduce the upfront costs of higher education to low income families and students, and as a way to capture some of the return on education investment (Barr 2004; Barr and Crawford 2005; Jacobs and van der Ploeg 2006). The consideration of longer term effects of public spending, especially for tertiary education are not dealt with here, but most certainly ought to be part of any serious policy discussion regarding the cost and distribution of education subsidies. Issues related to prices to charge tertiary immigrant students (Parsons and Smeeding 2006) and paying for increasingly sought 
after post tertiary professional and graduate degrees are key considerations for education ministers in all the countries studied here. However they are beyond the scope of this study

There may be a number of limitations to our analysis. First, due to data limitations, we assumed equal distribution of education expenditures per education level across all students, irrespective of their household's income level. Scant evidence from a number of countries suggests that students from higher socioeconomic background are overrepresented in faculties with higher spending per student (such as medicine and engineering). Second, there are good reasons for believing that the value of education benefits in-kind to recipients might be either higher or lower than government cost to produce these services. Future research should explore alternative valuation methods of in-kind benefits as well as examine in a more detailed manner the distribution of education benefits within countries. Last but not least, the distributional effects of in-kind benefits of public education should be analysed in combination with other in-kind incomes from both public and private sources as well as in a dynamic rather than static framework. 


\section{REFERENCES}

Antoninis, M. and P. Tsakloglou 2001. Who benefits from public education in Greece? Evidence and policy implications. Education Economics 9: 197-222.

Atkinson, A.B. 1970. On the measurement of inequality. Journal of Economic Theory 2: 244-263.

Atkinson, A.B. and F. Bourguignon. 2000. Introduction: Income distribution and economics. In Handbook of income distribution, ed. A.B. Atkinson and F. Bourguignon, Amsterdam and New York: Elsevier.

Atkinson, A.B., B. Cantillon, E. Marlier and B. Nolan. 2002. Social indicators: The EU and social inclusion. Oxford: Oxford University Press.

Atkinson, A.B., M. Rainwater and T.M. Smeeding. 1995. Income distribution in OECD countries: Evidence from the Luxembourg Income Study (LIS), Social Policy Studies No. 18. Paris: OECD.

Barr, N. 2004. Higher education funding, Oxford Review of Economic Policy 20: 264283.

Barr, N. and I. Crawford. 2005. Financing Higher Education: Answers from the UK. London: Rutledge.

Bell, L., G. Burtless, J. Gornick, and T.M. Smeeding. 2007. Failure to launch: Crossnational trends in the transition of economic independence. In The price of independence: The economics of early adulthood, ed. S. Danziger and C.E. Rouse New York: Russell Sage Press.

Callan T., T.M. Smeeding and P. Tsakloglou. 2007. Distributional effects of public education transfers in seven European countries. Working Paper 207, ESRI, Dublin.

Canberra Group, 2001. Final report and recommendations, The Canberra Group: Expert Group on Household Income Statistics, Ottawa.

Dearden, L., E. Fitzsimons, A. Goodman and G. Kaplan. 2008. Higher education funding reforms in England: The distributional effects and the shifting balance of costs. Economic Journal 118: F100-F125.

Dennis, I. and A.-C. Guio. 2003. Poverty and social exclusion in the EU after Laeken (Parts 1 and 2), Statistics in Focus Theme $3-8$ and 9/2003 Population and Living Conditions. Luxembourg: Eurostat.

Esping-Andersen, G. 1990. The Three Worlds of Welfare Capitalism, Cambridge, UK: Polity Press.

Evandrou, M., J. Falkingham, J. Hills and J. Le Grand. 1993. Welfare benefits in-kind and income distribution. Fiscal Studies 14: 57-76.

Förster, M. and M. Mira d'Ercole. 2004. Distribution and redistribution in OECD nations, Paris: OECD.

Garfinkel, I., L. Rainwater, and T.M. Smeeding. 2006. A reexamination of welfare state and inequality in rich nations: How in-kind transfers and indirect taxes change the story. Journal of Policy Analysis and Management 25: 855-919. 
Gustafsson, B. and M. Johansson. 1999. In search of smoking guns: What makes income inequality vary over time in different countries?. American Sociological Review 64: 585-605.

Harding, A., R. Lloyd and N. Warren. 2006. Moving beyond traditional cash measures of economic well-being: including indirect benefits and indirect taxes, National Centre for Social and Economic Modeling, Discussion Paper No. 61, University of Canberra.

Harris, T. 2000. The Effects of Taxes and Benefits on Household Income, 1997-98. Economic Trends No. 557: 45-83.

Haveman, R. and T.M. Smeeding. 2006. The Role of Higher Education in Social Mobility. Future of Children 16: 125-150.

Heady, C., T. Mitrakos and P. Tsakloglou. 2001. The distributional impact of social transfers in the EU: Evidence from the ECHP. Fiscal Studies 22: 547-565.

Hugounenq, R. 1998. Les Consommations publiques et la redistribution: Le Cas de l'éducation, Document de travail, Conseil de l'emploi, des revenus et de la cohésion sociale (CERC), Paris.

Jacobs, B. and F. van der Ploeg. 2006. Guide to reform of higher education: A European perspective. Economic Policy 47: 535-592.

James, E. and G. Benjamin. 1987. Educational distribution and income redistribution through education in Japan. Journal of Human Resources 22: 469-489.

Jones, F. 2006. The effects of taxes and benefits on household income, 2004-05. London: Office of National Statistics.

Kenworthy, L. 2004. Egalitarian Capitalism. New York: Russell Sage Foundation,.

Lakin, C. 2004. The effects of taxes and benefits on household income, 2002-2003. Economic Trends 607: 39-84.

Lambert, P.J. 2001. The distribution and redistribution of income: A mathematical analysis. $3^{\text {rd }}$ ed., Manchester: Manchester University Press.

Lampman R.J. 1984. Social welfare spending. New York: Academic Press,.

Marical, F., M. Mira d'Ercole, M. Vaalavuo and G. Verbist. 2006. Publicly-provided services and the distribution of resources. OECD Social, Employment and Migration Working Paper No. 45, Paris.

McLennan, W. 1996. The effects of government benefits and taxes on household income: 1993-94 Household Expenditure Survey. Australian Bureau of Statistics Report No. 6537.0.

OECD. 2006. Education at a glance 2006. Paris: OECD.

Parsons, C. and T.M. Smeeding. (ed.) 2006. Immigration and the transformation of Europe. Cambridge: Cambridge University Press.

Radner, D.B. 1997. Noncash income, equivalence scales and the measurement of economic well-being. Review of Income and Wealth 43: 71-88.

Sefton, T. 2002. Recent changes in the distribution of the social wage, Paper No 62, Centre for Analysis of Social Exclusion, LSE. 
Smeeding, T.M. 1977. The antipoverty effectiveness of in-kind transfers, Journal of Human Resources 12: 360-378.

1982a. Alternative methods for valuing selected in-kind transfer benefits and measuring their effect on poverty. U.S. Bureau of Census Technical Paper No. 50. Washington, DC.

T.M. 1982b. An anti-poverty effect of in-kind transfers: A 'good idea' gone too far?. Policy Studies Journal 10: 499-522.

Smeeding, T.M., P. Saunders, J. Coder, S.P. Jenkins, J. Fritzell, A.J.M. Hagenaars, R. Hauser and M. Wolfson. 1993. Poverty, inequality and living standard impacts across seven nations: the effects of non-cash subsidies for health, education and housing. Review of Income and Wealth 39: 229-256.

Steckmest, E. 1996. Noncash benefits and income distribution, LIS Working Paper No. 100, Luxembourg.

Titmus, R. 1958. Essays on the welfare state. London: Allen and Unwin.

Tsakloglou, P. and M. Antoninis. 1999. On the distributional impact of public education: evidence from Greece. Economics of Education Review 18: 439-452.

Whiteford, P. and S. Kennedy. 1995. Incomes and living standards of older people, Department of Social Security Research Report No 43 London.

Wilson, K. 2000. Using the PSID to examine the effects of school spending, Public Finance Review 28: 428-451.

Wilson, K., K. Lambright, and T.M. Smeeding. 2006. School finance, equivalent educational expenditure and income distribution: Equal dollars or equal chances for success?. Education Finance and Policy 1: 396-424.

Wolfe, B. and R. Haveman R. 2003. Social and non market benefits from education in an advanced economy. In Education in the 21st Century: Meeting the challenges of a changing world, ed. Y. Kodrzycki. Boston: Federal Reserve Bank of Boston. 